\title{
Kinerja Keuangan dan Manajemen Wakaf Sabilillah Malang
}

\section{(Financial Performance and Management Waqf of Sabilillah Malang)}

\author{
Wahyu Kharismaputri*, Ulfi Kartika Oktaviana \\ Jurusan Perbankan Syariah, Fakultas Ekonomi, Universitas Islam Negeri Maulana Malik Ibrahim Malang \\ Jl. Gajayana No. 50 Malang \\ E-mail:wahyukharismaputri61@gmail.com
}

\begin{abstract}
Abstrak
Meningkatkan kinerja sangat penting dalam setiap organisasi termasuk lembaga wakaf. Menilai kinerja bisa berguna untuk menunjukkan apakah mereka telah secara efektif dan efisien dalam mengelola harta wakaf. Dalam konteks organisasi nirlaba seperti lembaga wakaf yang bertujuan untuk mensejahterakan masyarakat masih kurang menyadari pentingnya menilai kinerja. Manajemen wakaf sangat diperlukan untuk berlangsungnya kebermanfaatan harta wakaf. Wakaf akan memberikan kemanfaatan bagi ummat jika dikelola secara professional. Nadzir wajib mengelola dan mengembangkan harta benda wakaf sesuai dengan tujuan, fungsi, dan peruntukkannya. Penelitian ini menggunakan metode kualitatif dengan pendekatan deksriptif, yang bertujuan untuk mengetahui kinerja keuangan dan manajemen wakaf di Masjid Sabilillah Malang. Pengumpulan data dilakukan dengan cara wawancara, observasi, dan studi pustaka. Hasil penelitian menunjukkan bahwa kinerja keuangan cukup baik karena memenuhi kriteria dari ketujuh rasio keuangan. Manajemen wakaf di Sabilillah juga terorganisir dengan baik sesuai dengan jobdisk masing-masing. Dalam manajemen wakaf di masjid Sabilillah menggunakan prinsip al-amin (siddiq, amanah, tabliq, dan fathanah). Dalam pengelolaan harta wakaf mengalami kendala seperti nadzir yang masih pasif dalam mengawasi pengelolaan wakaf, namun segala sesuatu dilaksanakan dengan semaksimal mungkin dan direncanakan dengan maksimal untuk memberikan pemahaman yang sama pada pengelola wakaf di masjid Sabilillah.
\end{abstract}

Kata Kunci: pengukuran kinerja, lembaga wakaf, manajemen wakaf.

\begin{abstract}
Improving performance is critical in every organization including waqf institutions. Assessing performance can be useful to indicate whether they have been effective and efficient in managing waqf assets. In the context of non-profit organizations such as waqf institutions that aim to prosper the community still do not realize the importance of assessing performance. Waqf management is indispensable for the usefulness of waqf assets. Waqf will provide benefits for ummah if managed professionally. Nadzir is obliged to manage and develop waqf property in accordance with its purpose, function, and provision. This research uses qualitative methods with a deksriptif approach, which aims to know the financial performance and management of waqf in Sabilillah Mosque Malang. Data collection is done by means of interviews, observations, and library studies. The results showed that financial performance is quite good because it meets the criteria of the seven financial ratios. Waqf management in Sabilillah is also well organized according to their respective jobdisks. In waqf management in Sabilillah mosque use the principles of al-amin (siddiq, amanah, tabliq, and fathanah). nature of waqf property management has obstacles such as nadzir who are still passive in overseeing the management of waqf, but everything is implemented to the maximum extent possible and planned to give the same understanding to the waqf manager at Sabilillah mosque.
\end{abstract}

Keywords: performance measurement, waqf Institute, waqf management.

\section{Pendahuluan}

Keuangan islam tidak hanya digunakan kalangan umat muslim, namun digunakan oleh kalangan non-muslim. Muculnya keuangan islam sebagai sistem keuangan praktis di tengah krisisnya dunia keuangan yang sejauh ini tidak efektif (Laldin dan Furqani, 2013). Keuangan islam pada dasarnya didorong bahwa bisa memberi prespektif yang koheren untuk memahami masalah ekonomi riil serta sebagai alternatif dasar untuk pengelolaan ekonomi dan keuangan untuk mencapai kemakmuran umat.

Wakaf dipandang sebagai salah satu lembaga yang potensial untuk merangsang pembangunan ekonomi dan sosial masyarakat (Arshad et al., 2018). Wakaf dalam hal ekonomi dianggap cukup baik dan potensial untuk mewujudkan kebijakan sesuai dengan harta wakaf. Wakaf dapat memberikan dampak yang besar pada kesejahteraan sosial dan ekonomi masyarakat ketika pengelolaannya efektif dan efisien (Arshad et al., 2018). Pengembangan ekonomi wakaf harus didorong dengan tingkat kesadaran terutama oleh nadzir wakaf sehingga pemberdayaan wakaf dapat ditingkatkan dengan produktif. Secara ekonomi, wakaf berkontribusi positif terhadap ekspansi ekonomi domestik melalui pengembangan usaha sosial dan menjadi alat pengentasan kemiskinan yang efektif untuk mengurangi ketidaksetaraan pendapatan (Noordin et al, 2017).

Dalam penelitian Shafii et al (2012) menyatakan bahwa di Singapura dan Malaysia mengalami pertumbuhan dalam wakaf uang. Kedua lembaga tersebut mampu menghasilkan pendapatan dari operasional wakaf secara efisien. Menurut Arief (2011) lembaga wakaf di Indonesia belum maksimal sebagai instrument pemberdayaan umat, karena disebabkan oleh beberapa hal seperti, aspek kelembagaan, aspek kesadaran hukum, dan aspek manajemen. Hal ini dapat dikatakan bahwa wakaf dapat diberdayakan secara maksimal

\footnotetext{
* Corresponding author
} 
apabila ketiga aspek tersebut saling bersinergi. Sebaliknya, jika dari aspek-aspek tersebut tidak terpenuhi akan mengakibatkan pengelolaan kurang maksimal. Masalah yang dihadapi lembaga wakaf lainnya adalah aspek institusi, menurut Menteri Agama menyatakan bahwa kualitas sumber daya manusia di lembaga wakaf masih lemah (Arief, 2011).

Berdasarkan data provinsi Jawa Timur merupakan terbesar ketiga di Indonesia mempunyai lokasi tanah wakaf sebanyak 63.804 lokasi tanah wakaf (Siwak Kemenag, 2020). Dari data tersebut di Kabupaten Malang dan Kota Malang terdapat 7.620 lokasi tanah wakaf (Siwak Kemenag, 2020). Banyaknya lokasi tanah wakaf membuat lembaga wakaf di Malang mempunyai potensi untuk mengentaskan kemiskinan. Jika wakaf dikembangkan dengan baik maka bisa membantu pertumbuhan ekonomi, pembangunan, sosial, dan budaya. Menurut Zuki (2012) dalam Shafii et al (2012) mengemukakan bahwa ada ruang untuk meningkatkan manajemen dan bisnis lembaga wakaf dengan mengadopsi pendekatan modern dan menyediakan layanan yang lebih baik dan efisien untuk masyarakat. Oleh karena itu, sangat penting bagi lembaga wakaf secara efektif dan efisien dikelola dalam menciptakan pengembangan harta wakaf.

Berdasarkan hasil survey awal peneliti membandingkan dengan penelitian sebelumnya Abas (2018) menyatakan bahwa manajemen wakaf harus ditangani terutama oleh lembaga wakaf, sehingga perlu diadakan penelitian lebih lanjut mengenai pengukuran kinerja keuangan dan manajemen wakaf Sabilillah Malang.

Arshad (2017) dengan indikator penelitian kinerja keuangan dan kinerja operasional menghasilkan bahwa mengelola uang publik didasarkan pada transparansi dan akuntabilitas. Proses audit kerja sangat diperlukan untuk lembaga wakaf yang memiliki sifat yang berbeda dari organisasi non-profit lainnya. Penelitian lainnya Noordin (2017) menjelaskan bahwa kebanyakan lembaga wakaf bergantung pada laporan keuangan dan indikator ekonomi untuk melaporkan kepada stakeholder tentang kinerja lembaga wakaf. Menurut penelitian Arshad (2017) pengukuran kinerja lembaga wakaf dapat meningkatkan jumlah sifat wakaf, meningkatkan kesadaran, dan signifikan wakaf di kalangan masyarakat. Hal ini menunjukkan bahwa pentingnya dalam mengukur kinerja suatu lembaga bisa dinilai dari aspek mana saja seperti aspek keuangan atau aspek lainnya.

\section{Kajian Teori}

\section{Wakaf}

Wakaf yang dikemukakan oleh ulama ahli fiqih adalah menahan sebagian harta yang dipunya untuk dimanfaatkan bagi kemaslahatan ummat. Namun, dalam empat madzhab memiliki pendapat yang berbeda terkait wakaf. Dalam buku fikih wakaf (Kemenag, 2006) dimulainya wakaf dalam islam yaitu pada masa Rasulullah SAW. Sebagian jumhur ulama berpendapat bahwa Rasulullah adalah yang pertama kali menjalankan wakaf.

Menurut UU No. 41 Tahun 2004 tentang wakaf menyatakan bahwa wakaf merupakan perbuatan hukum yang dilakukan oleh wakif untuk memisahkan atau menyerahkan Sebagian hartanya untuk dikelola dan dimanfaatkan dalam jangka waktu tertentu dengan tujuan untuk mensejahterakan ummat. Keistimewaan ibadah wakaf terlihat dari beberapa hal.
Pertama, sistem yang Rabbani yaitu sistem yang berasal dari petunjuk wahyu Allah SWT dan bimbingan Rasulullah SAW. Kedua, sistem yang universal amalan wakaf tidak hanya terbatas pada wakaf untuk keluarga tetapi termasuk juga untuk kepentingan umum. Wakaf dalam peraturanpemerintah memperhatikan 3 hal yaitu wakif atau orang yang mewakafkan, pemisahan tanah milik belum menunjukkan bukti pemindahan kepemilikan, dan tanah yang digunakan untuk kepentingan ibadah.

\section{Kinerja Keuangan}

Kinerja sering disebut dengan performa atau performance. Kinerja merupakan output yang dihasilkan oleh indikator dalam suatu pekerjaan (Wirawan, 2009). Menurut Mengkunegara (2001) kinerja merupakan kuantitas dan kualitas yang telah diraih seorang karyawan dalam menjalankan tanggung jawab yang telah diberikan. Kualitas yang dimaksud adalah cara kerja dan ketekunan dalam menjalankan setiap pekerjaan. Sedangkan kuantitas adalah dinilai dari seberapa banyak jumlah pekerjaan yang telah dikerjakan dalam masa kerja.

Lembaga wakaf tidak dapat dievaluasi menggunakan rasio keuangan seperti, aktiva lancar yang tinggi didominasi oleh kas dan setara kas. Rasio keuangan merupakan hal yang sangat penting untuk mengevaluasi keadaan keuangan dalam suatu organisasi, namun rasio bukan tindakan paling sukses di organisasi non-profit seperti wakaf (Shafii et al., 2012). Namun, ada beberapa kelemahan yang dapat dikaitkan dengan penerapan rasio dalam mengukur kinerja wakaf (Arshad dan Zain, 2017). Sebuah organisasi dapat meningkatkan efektivitas jika memiliki dana yang cukup dan dukungan dari penyandang dana. Oleh karena itu, lembaga wakaf perlu mempertimbangkan aspek non-keuangan dari pengukuran kinerja karena hal ini memberikan cakupan yang lebih luas dan informasi akuntabilitas kepada para stakeholder.

Dari program sosial yang dilakukan oleh masjid Sabililllah dalam bentuk distribusi dari wakaf yang disalurkan oleh wakif maupun distribusi dari hasil investasi, maka sektor utama yang menjadi total ukur Sabilillah adalah Pendidikan, sosial, dan ekonomi ummat. Dalam lingkungan organisasi non-profit ada tiga karakteristik yang memainkan peran penting dalam kinerja organisasi yaitu tujuan organisasi, pencapaian, dan efisiensi organisasi (Shafii, 2012). Epstein dan Buhovac (2009) mengusulkan empat kategori rasio yang digunakan dalam efisiensi dan keberlanjutan lembaga wakaf melalui program-programnya. Kategori tersebut terdiri dari efisiensi administrasi, efisiensi program, efisiensi penggalangan, dan ukuran kinerja. Pengukuran kinerja lembaga nirlaba seperti lembaga zakat bisa menggunakan dengan metode kuantitatif. Ritchei dan Kolodinsky (2003) dalam penelitiannya di sebuah universitas menilai 16 rasio yang dibagi menjadi 4 bagian, yaitu kinerja keuangan, rasio dukungan public, rasio efisiensi penghimpunan dana, dan kinerja investasi. Dalam penelitian tersebut menyatakan tidak semua rasio digunakan untuk menilai sebuah kinerja organisasi nirlaba.

Penelitian ini merupakan hasil modifikasi rasio keuangan dari penelitian Ritchei \& Kolodinsky (2003) dan Shafii et al (2012): 
Tabel Ukuran Kinerja

\begin{tabular}{|c|c|c|c|}
\hline Kategori & Rasio & Ukuran kinerja & Rumus \\
\hline \multirow{10}{*}{$\begin{array}{l}\text { Kinerja } \\
\text { Keuangan }\end{array}$} & Total Aset & Aset yang dihasilkan dalam penghimpunan wakaf & total pendapatan \\
\hline & & & total aset \\
\hline & Pendapatan & Pendapatan yang dihasilkan dari kegiatan & penghasilan \\
\hline & Operasional & & beban \\
\hline & Pertumbuhan & Penghasilan pendapatan dari aktivitasnya & incth $n-\operatorname{incth}(n-1)$ \\
\hline & Pendapatan & & incth $(n-1)$ \\
\hline & Kontribusi Program & Kontribusi dalam program lembaga & total kontribusi \\
\hline & & & $\overline{\text { total pendapatan }}$ \\
\hline & Biaya & Penghimpunan dana yang diperoleh lembaga & total kontribusi \\
\hline & $\begin{array}{l}\text { Penghimpunan } \\
\text { Dana }\end{array}$ & & penggunaan dana \\
\hline \multirow{5}{*}{$\begin{array}{l}\text { Kinerja } \\
\text { Operasional }\end{array}$} & Efisiensi & Presentase biaya yang dihabiskan untuk biaya & biaya admin \\
\hline & Administrasi & administrasi & jumlah beban \\
\hline & Efisiensi Program & Biaya yang dihabiskan dalam kegiatan & biaya program \\
\hline & & & jumlah beban \\
\hline & $\begin{array}{l}\text { Ketersediaan Uang } \\
\text { Tunai }\end{array}$ & Presentase saldo kas dan bank & $\frac{\text { kas }+ \text { saldobank }}{\text { totalaset }}$ \\
\hline
\end{tabular}

Sumber: modifikasi penelitian Rirtchei dan Kolodinsky (2003) dan Shafii et al (2012)

\section{Metode}

\section{Jenis Penelitian}

Penelitian ini menggunakan kualitatif dengan metode pendekatan desktiptif. Penelitian kualitatif adalah penelitian yang tidak menggunakan alat statistic. Dalam penelitian ini ditujukan untuk mendeskripsi dan menganalisis peristiwa, fenomena, pemikiran orang secara kelompoka atau individu dan sosial (Sutopo dan Arief, 2010).

\section{Jenis dan Sumber Data}

Sumber data yang diperoleh merupakan hal yang penting dalam sebuah penelitian. Jenis data yang digunakan dalam penelitian ini adalah data primer dan data sekunder. Data primer diperoleh langsung dari sumbernya dengan cara observasi atau pengamatan, wawancara, dan dokumentasi. Sedangkan, data sekunder diperoleh secara tidak langsung dengan melihat laporan keuangan. Laporan keuangan yang digunakan selama 3 tahun terakhir (2016-2018).

\section{Metode Analisis Data}

Analisis data menggunakan alat rasio keuangan. Rasio keuangan yang digunakan dalam penelitian ini adalah rasio Ritchei \& Kolodinsky (2003) dan Shafii et al (2012). Rangkaian analisis data dilakukan dengan cara berikut:

1. Reduksi data yaitu merangkum, memilih, dan memfokuskan pada hal yang penting. Dalam penelitian ini data diambil dari observasi, wawancara, dan data pendukung lainnya,

2. Penyajian data dilakukan dengan bentuk uraian, bagan, hubungan antar kategori (Sugiyono, 2008),

3. Kesimpulan merupakan keputusan yang diperoleh berdasarkan metode berpikir baik induktif atau deduktif, dan

4. Triangulasi adalah pengumpulan data dari berbagai sumber yang berbeda dengan menggunakan metode yang sama.

\section{Hasil dan Pembahasan}

\section{Hasil}

\section{Kinerja Keuangan}

Wakaf dijalankan dengan kemampuan individu dalam anggaran dan hajatnya. Harta wakaf sebagai investasi pada aset produktif yang akan dikelola oleh nadzir. Hasil wakaf akan didistribusikan untuk program-program sosial dan diambil manfaatnya untuk disalurkan pada penerima manfaat.

Berdasarkan perhitungan dari modifikasi penelitian Ritchei \&Kolodinsky (2003) dan Shafii et al (2012) sebagai berikut:

Tabel 1. Pengukuran Kinerja Wakaf Sabilillah Malang

\begin{tabular}{lllllll}
\hline $\begin{array}{l}\text { Kate } \\
\text { gori }\end{array}$ & Rasio & 2016 & 2017 & 2018 & $\begin{array}{l}\text { Rata } \\
\text {-rata }\end{array}$ & $\begin{array}{l}\text { Kesim } \\
\text { pulan }\end{array}$ \\
\hline $\begin{array}{l}\text { Kine } \\
\text { rja }\end{array}$ & $\begin{array}{l}\text { Total } \\
\text { Aset }\end{array}$ & 0,95 & 1,25 & 1,09 & 1,09 & Efisien \\
$\begin{array}{l}\text { Keua } \\
\text { ngan }\end{array}$ & $\begin{array}{l}\text { Pendapat } \\
\text { an }\end{array}$ & 1,23 & 1,24 & 1,25 & 1,24 & Efisien \\
& $\begin{array}{l}\text { Operasio } \\
\text { nal } \\
\text { Pertumbu } \\
\text { han }\end{array}$ & 1,37 & 0,57 & 0,11 & 0,68 & Efisien \\
& $\begin{array}{l}\text { Pendapat } \\
\text { an }\end{array}$ & & & & & \\
& $\begin{array}{l}\text { Kontribu } \\
\text { si }\end{array}$ & 0,55 & 0,48 & 0,55 & 0,52 & Tidak \\
& $\begin{array}{l}\text { Program } \\
\text { Biaya }\end{array}$ & 0,71 & 0,70 & 0,69 & 0,7 & $\begin{array}{l}\text { Tidak } \\
\text { Efisien }\end{array}$ \\
& $\begin{array}{l}\text { Penghim } \\
\text { punan } \\
\text { Dana }\end{array}$ & & & & & \\
$\begin{array}{l}\text { Kinisiensi } \\
\text { rja }\end{array}$ & 0,85 & 0,82 & 0,86 & 0,84 & Efisien \\
$\begin{array}{l}\text { Erogram } \\
\text { Oper } \\
\text { asion } \\
\text { al }\end{array}$ & $\begin{array}{l}\text { Ketersedi } \\
\text { aan Uang }\end{array}$ & 0,03 & 0,01 & 0,07 & 0,03 & Efisien \\
Tunai & & & & & \\
\hline
\end{tabular}


Dilihat tabel 1 nilai rasio masing-masing mengalami naik dan turun. Dari ketujuh rasio yang digunakan 2 di antara rasio tersebuut tidak efisien karena kurang dari standard yang ada.

\section{Manajemen Wakaf}

Pengelolaan harta wakaf bertujuan untuk mengembangkan dan memaksimalkan harta wakaf sehingga dapat meingkatkan kesejahteraan ummat. Pemanfaatan wakaf dilakukan dengan produktif dan konsumtif. Pengelolaan secara produktif bisa membuka pekerjaan baru yang bisa meringankna beban ekonomi ummat. Dalam pengelollan wakaf, nadzir membutuhkan kecakapan manajemen untuk menjalankan tugas. Manajemen digunakan untuk tetap memberi hubungan baik antara wakif, masyarakat, dan nadzir. Fungsi manajemen yang harus dipahami oleh nadzir ada 4 macam, yairu perencanaan, pengorganisasian, pengimplementasian, dan pengawasan

a. Perencanaan (Program nadzir), dalam melaksanakan tugasnya Yayasan Sabilillah membuat rencana kerja selama setahun kedepan. Dalam penghimpunan dana yang dilakukan oleh Sabilillah salah satunya adalah minimarket dan pujasera. Hal ini dikembangkan untuk tetap menjaga kebermanfaatan harta wakaf.

b. Pengorganisasian, dilakukan dengan menentukan dan mengelompokkan kegiatan untuk menjalankannya. Pengorganisasian yang dilakukan oleh Yayasan Sabilillah adalah dengan pembagian kerja sesuai dengan jobdisk masing-masing.

c. Pengimplementasian, yujuannya adalah agar semua pihak (nadzir) dapat menjalankan pekerjaan dengan tanggungjawab. Pengimplementasian dilakukan sesuai dengan program yang telah disusun pada tugas masingmasing bagian.

d. Pengawasan, merupakan proses yang dilakukan untuk memastikan seluruh kegiatan yang dilaksanakan berjalan sesuai rencana awak. Dalam proses pengawasan ada 2 macam tanggungjawab yang dilakukan oleh nadzir yaitu pengawasan langsung dan pengawasan tidak langsung.

\section{Pembahasan}

\section{Kinerja Keuangan}

\section{Rasio total asset}

Untuk menghitung rasio ini akun yang digunakan adalah total pendapatan dan total aset. Hasil perhitungan rasio total pendapatan dibagi total aset pada laporan keuangan masjid Sabilillah Malang selama 3 tahun terakhir ditunjukkan pada tabel 4.8 berikut.

Tabel 2. Rasio Total Asset Masjid Sabilillah Tahun 20162018

\begin{tabular}{lcccc}
\hline Rasio Pengukuran & \multicolumn{3}{c}{ Tahun } & \multirow{2}{*}{ Rata-rata } \\
\cline { 2 - 4 } & 2016 & 2017 & 2018 & \\
\hline Total Asset & 0,95 & 1,25 & 1,09 & 1,09 \\
\hline Sumbr: data diolah & & &
\end{tabular}

Sumber: data diolah

Berdasarkan tabel 2 terlihat bahwa secara umum rasio ini mengalami naik turun selama 3 tahun terakhir. Rata-rata rasio ini adalah 1,09 yang artinya bahwa setiap Rp 1 dana yang diputarkan oleh masjid Sabilillah dalam bentuk aset mampu memperoleh dana Rp 1,09. Berdasarkan teori bahwa "rasio di atas menunjukkan bahwa organisasi memilki pendapatan yang sedikit di bawah penialian aset pada akhir periode" (Karens, 2008).

Pada tahun 2016 rasio ini mengalami kondisi kurang baik yaitu 0,95. Hal ini diartikan bahwa setiap Rp 1 dana yang diputarkan oleh masjid Sabilillah dalam bentuk asset untuk memperoleh dana tidak mendapat hasil yang maksimal. Namun pada tahun berikutnya tahun 2017-2018 mengalami peningkatan yaitu 1,25 dan 1,09 yang artinya bahwa setiap Rp 1 dana yang diputarkan oleh masjid Sabilillah mendapatkan hasil yang maksimal.

\section{Pendapatan operasional}

Rasio ini digunakan untuk mengukur biaya operasional terhadap total penghimpunan. Perhitungan ini dilakukan dengan cara penghasilan dibagi dengan beban.

Tabel 3. Pendapatan Operasional Masjid Sabilillah Tahun 2016-2018

\begin{tabular}{lcccc}
\hline Rasio Pengukuran & \multicolumn{3}{c}{ Tahun } & Rata-rata \\
\cline { 2 - 4 } & 2016 & 2017 & 2018 & \\
\hline $\begin{array}{l}\text { Pendapatan } \\
\text { Operasional }\end{array}$ & 1,23 & 1,24 & 1,25 & 1,24 \\
\hline
\end{tabular}

Sumber: data diolah

Dari tabel 3 kinerja keuangan masjid Sabilillah hasil yang baik. Rata-rata dari rasio ini selama 3 tahun terkahir berada pada posisi 1,24. Hal ini menunjukkan bahwa rasio ini dapat dikatakan efisien. Menurut penelitian Risdan (2016) jika nilai $\mathrm{R}$ lebih kecil dari 12,5\% menunjukkan bahwa pendapatan yang dihasilkan oleh suatu lembaga dikatakan efisien.

\section{Pertumbuhan pendapatan}

Rasio ini digunakan untuk mengukur efisiensi biaya terhadap pendapatan yang berhasil dihimpun. Menurut Rusdan (2016) memgatakan bahwa jik $\mathrm{R}<2 \%$ maka dikatakan efisien, sedangkan jika $2 \% \leq \mathrm{R} \leq 5 \%$ dikatakan cukup efisien, dan jika $\mathrm{R}>5 \%$ maka dapat dikatakan tidak efisien.

Tabel 4. Pertumbuhan Pendapatan Masjid Sabilillah Tahun 2016-2018

\begin{tabular}{lcccc}
\hline Rasio Pengukuran & \multicolumn{3}{c}{ Tahun } & Rata-rata \\
\cline { 2 - 5 } & 2016 & 2017 & 2018 & \\
\hline $\begin{array}{l}\text { Pertumbuhan } \\
\text { Pendapatan }\end{array}$ & 1,37 & 0,57 & 0,11 & 0,68 \\
\hline
\end{tabular}

Sumber: data diolah

Berdasarkan tabel 4 kinerja keuangan masjid Sabilillah menurut rasio ini menunjukkan hasil yang efisien. Rata-rata pendapatan sebesar 0,68 yang artinya kurang dari 2\% maka dapat diartikan efisien. Pada tahun 2016 rasio ini sebesar 1,37 yang mendekati $2 \%$ namun masih dikatakan efisien.

\section{Kontribusi program}

Rasio ini menunjukkan seberapa besar dana yang diperoleh organisasi dari sumber sukarela atau non-publik. Rasio ini dihitung dengan total kontribusi dibagi total pendapatan. Menurut Karens (2008) "Apabila rasio di atas 0,50 menunjukkan bahwa pendapatan utama organisasi bergantung pada dukungan sukarela. Sedangkan jika niali di bawah 0,50 menunjukkan bahwa pendapatan bergantung pada dukungan public atau masyarakat. 
Tabel 5. Kontribusi Program Masjid Sabilillah Tahun 20162018

\begin{tabular}{lrrrc}
\hline Rasio Pengukuran & \multicolumn{3}{c}{ Tahun } & Rata-rata \\
\cline { 2 - 4 } & 2016 & 2017 & 2018 & \\
\hline Kontribusi & 0,55 & 0,48 & 0,55 & 0,52 \\
Program & & & & \\
\hline
\end{tabular}

Sumber: data diolah

Berdasarkan tabel 5 kinerja keuangan masjid Sabilillah ratarata hasil perhitungan rasio ini berada pada posisi 0,52 yang artinya pendapatan utama organisasi bergantung padadukungan sukarela. Pada tahun 2017 menunjukkan angka 0,48 yang artinya bahwa organisasi mengalami penurunan yang pada tahun tersebut organisasi bergantung pada dukungan publik.

\section{Biaya penghimpunan dana}

Rasio ini digunakan untuk mengetahui seberapa besar biaya yang bersumber dari dana kontribusi. Rasio ini dihitung dengan cara total kontribusi dibagi total penggunaan dana. Menurut Karens (2008) "Nilai rasio di atas 1,0 menunjukkan bahwa kontribusi melebihi biaya, sedangkan nilai kurang dari 1,0 menunjukkan bahwa biaya lebih besar dari total kontribusi”.

Tabel 6. Penghimpunan Dana Masjid Sabilillah Tahun 20162018

\begin{tabular}{lcccc}
\hline Rasio Pengukuran & \multicolumn{3}{c}{ Tahun } & Rata-rata \\
\cline { 2 - 5 } & 2016 & 2017 & 2018 & \\
\hline Penghimpunan & 0,71 & 0,70 & 0,69 & 0,7 \\
Dana & & & & \\
\hline
\end{tabular}

Sumber: data diolah

Berdasarkan tabel 6 rasio ini memperoleh rata-rata sebesar 0,7 artinya proporsi penggunaan dana lebih besar dibanding total kontribusi. Setiap tahun mengalami kenaikan sebesar $0,1 \%$ yang berarti biaya yang dikeluarkan lebih besar daripada total kontribusi yang dikeluarkan oleh lembaga.

\section{Efisiensi program}

Rasio ini digunakan untuk operasional lembaga tahun ini terhadap tahun sebelumnya. Menurut Rusdan (2016) "Jika R $\leq 1$ maka diartikan selaras dan jika $\mathrm{R}$ > 1 maka diartikan tidak selaras. Maka dapat disimpulkan bahwa semakin tinggi biaya yang dikeluarkan maka tidak efisien bagi lembaga".

Tabel 7. Efisiensi Program Masjid Sabilillah Tahun 20162018

\begin{tabular}{ccccc}
\hline Rasio Pengukuran & \multicolumn{3}{c}{ Tahun } & Rata-rata \\
\cline { 2 - 4 } & 2016 & 2017 & 2018 & \\
\hline Efisiensi Program & 0,85 & 0,82 & 0,86 & 0,84 \\
Sumber: data diolah & & & &
\end{tabular}

Berdasarkan tabel 7 rasio ini memperoleh rata-rata sebesar 0,84 yang artinya setiap tahunnya dalam efisiensi program dilakukan dengan selaras. Karena nilai efisiensi kurang dari 1 maka dapat diartikan selaras.

\section{Ketersediaan uang tunai}

Rasio ketersediaan uang tunai merupakan presentase saldo kas dan bank. Semakin tinggi ketersediaan uang tunai di bank dianggap kinerja organisasi itu baik.
Tabel 8. Ketersediaan Uang Tunai Masjid Sabilillah Tahun 2016-2018

\begin{tabular}{lcccc}
\hline Rasio Pengukuran & \multicolumn{3}{c}{ Tahun } & Rata-rata \\
\cline { 2 - 4 } & 2016 & 2017 & 2018 & \\
\hline Ketersediaan & 0,03 & 0,01 & 0,07 & 0,03 \\
Uang Tunai & & & & \\
\hline
\end{tabular}

Sumber: data diolah

Berdasarkan tabel 8 rata-rata ketersediaan uang tunai di bank sebesar 0,03 yang artinya kinerja dalam organisasi tersebut tidak baik karena aset lancar yang dimiliki tidak mampu memenuhi kebutuhan jangka panjang.

\section{Manajemen Wakaf}

Wakaf akan memberikan kemanfaatan bagi ummat jika dikelola secara professional. Nadzir wajib mengelola dan mengembangkan harta benda wakaf sesuai dengan tujuan, fungsi, dan peruntukkannya. Menurut Abu Hanifah wakaf berarti menahan suatu benda yang menurut hukum benda tersebut masih milik wakif. Berdasarkan definisi tersebut maka kepemilikan harta wakif tidak lepas penuh dari si wakif, bahkan ia boleh menarik dan boleh menjualnya (Direktorat Pemberdayaan Wakaf, 2007). Tujuan dari pengelolaan wakaf adalah untuk memaksimalkan potensi harta wakaf dan mengembangkan wakaf sehingga mampu meningkatkan kesejahteraan ekonomi dan sosial bagi ummat. Melakukan pengelolaan wakaf berarti mengembangkan harta wakaf secara produktif untuk generasi yang akan datang sesuai dengan tujuan wakaf (Hakim, 2010).

Berdasarkan hasil penelitian yang dilakukan di masjid Sabilillah Malang maka dapat disimpulkan bahwa wakaf di Sabilillah menganut salah satu mazhab yaitu mazhab Syafi'i karena tidak ada pembatasan terhadap nadzir untuk mengelola harta wakaf yang sudah diserahkan kepada pihak Sabilillah. Harta wakaf yang disalurkan di Sabilillah akan dimanfaatkan untuk PUJASERA dan minimarket yang berada disektor bisnis. Selain itu, wakaf sabilillah juga menerima wakaf tunai yang nantinya wakaf tunai akan dikembangkan oleh pihak koperasi Sabilillah. Wakaf tunai akan diinvestasikan lewat produk yang ditawarkan oleh koperasi Sabilillah. Oleh karena itu, maka dapat disimpulkan bahwa wakaf di Sabilillah ada dua macam yaitu wakaf produktif dan wakaf tunai. Wakaf produktif digunakan untuk mengembangkan minimarket dan PUJASERA, sedangkan wakaf tunai akan diinvestasikan kepada koperasi Sabilillah.

Harta wakaf bisa memberikan manfaat bagi ummat apabila dikelola secara profesional. Pengelolaan wakaf dapat dioptimalkan dengan pengelolaan secara professional mulaui dari penghimpunan, investasi, dan pendistribusian.

\section{Penghimpunan}

Hal yang paling utama dalam mengelola wakaf adalah menghimpun dana wakaf dari wakif. Penghimpunan harta wakaf termasuk memengaruhi masyarakat agar melakukan amal kebajikan degan berwakaf. Nadzir memiliki kapasitas khususnya untuk menghimpun harta wakaf secara professional sehingga lembaga wakaf mampu menjalankan tugasnya dengan baik.

Nadzir bertugas untuk menghimpun dan awakaf untuk menjaga kebermanfaatan harta wakaf tersebut. Menurut penelitian yang dilakukan di masjid Sabilillah penghimpunan 
dana wakaf cukup besar diperoleh secara mandiri seperti masjid, parkir, auditorium.

Ada empat fungsi yang harus dipahami oleh nadzir dalam penghimpunan yaitu perencanaan, pengorganisasian, pengimplementasian, dan pengawasan. Dari keempat fungsi tersebut semuanya sudah dijalankan oleh nadzir masjid Sabilillah. Berikut adalah keempat pelaksanaan fungsi manajemen yang dilakukan oleh nadzir:

\section{a. Perencanaan (planning)}

Perencanaan dalam pengelolaan minimarket merupakan usaha dari masjid Sabilillah untuk tetap menjaga keutuhan harta wakaf. Nadzir harus mempunyai jiwa entrepreneur untuk mengembangkan wakaf produktif agar manfaatnya tetap terjaga. Dalam penghimpunan dana yang dilakukan oleh pengurus masjid Sabilillah bekerjasama dengan beberapa instansi terkait seperti SD Islam Anak Saleh Tunggalwulung bekerjasama dalam mendirikan koperasi. Dengan sistem sewa yang diterapkan pada minimarket, maka penghimpunan dana yang dilakukan nadzir kurang maksimal. Pendistribusian harta wakaf juga termasuk dalam rencana kerja masjid Sabilillah, pendistribusian disalurkan kepada guru-guru diniyah, petugas khotib, tenaga kebersihan, dan bantuan sosial pada warga sekitar.

\section{b. Pengorganisasian (organizing)}

Pengorgaanisasian dilakukan dengan tujuan membagi kegiatan yang besar agar menjadi lebih ringan. Hal ini penting dilakukan karena dengan adanya pengorganisasian yang jelas nadzir bisa menjalankan tugasnya dengan baik. Dalam hal pengelolaan wakaf nadzir akan membagi tugas pokok sesuai dengan tugasnya. Namun dalam pengambilan keputusan akan dilakukan dengan musyawarah Bersama.

Analisis dari struktur organisasi wakaf yang dikelola masjid Sabilillah Malang, terbagi dalam beberapa bidang yaitu pengembangan kerjasama dan hukum, usaha dan marketing, dan IT dan media. Dalam hal ini meskipun semua dibagi menjadi beberapa bagian namun semua anggota harus bisa dalam hal segala bidang. Dalam hal kerjasama masjid Sabilillah mengajak sekolah dan investor untuk bekerjasama dalam bidang pengembangan minimarket. Marketing dalam hal ini memasarkan produk wakaf yang ada di masjid Sabilillah dengan strategi pengembangan wakaf produktif seperti pengembangan majelis ta'lim di lingkungan Sabilillah. Oleh karena itu, sumber daya manusia (SDM) yang ada di Sabilillah harus sesuai dengan kriteria yang disarankan oleh Badan Wakaf Indonesia (BWI).

\section{c. Pengimplementasian (Directing)}

Pengimplementasian merupakan program yang harus dijalankan oleh nadzir dalam organisasi serta memotivasi anggotanya agar tetap bertanggungjawab dengan penuh dan produktivitas yang tinggi. Seperti pengimplementasian lahan parkir Sabilillah dikelola dengan baik karena bisa menunjang pendapatan Sabilillah. Pengimplementasian dalam hal ini seperti terlaksananya program kerja yang telah direncanakan seperti pendistribusian harta wakaf, pengembangan wakaf. Program kerja yang direncanakan oleh pengurus tidak semuanya bisa dapat dijalankan. Namun nadzir tetap berusaha agar segala sesuatu yang dilaksanakan untuk memberikan pemahaman yang sama, tokoh-tokoh yang sudah mengelola Sabilillah sehingga dengan pengorbanan dan pemaparan itu kendala akan berkurang.

\section{d. Pengawasan (Controlling)}

Pengawasan merupakan proses yang dilakukan untuk memastikan seluruh rangkaian kegiatan yang telah direncanakan bisa berjalan sesuai target. Pengawasan yang dilakukan oleh pihak Sabilillah yaitu ada pengawasan langsung dan pengawasan tidak langsung. Pengawasan langsung dilakukan oleh nadzir yang terjun langsung ke lapangan untuk meninjau pengelolaan seperti lahan parkir, masjid, dan minimarket. Sednagkan pengawasan tidak langsung dilakukan oleh bagian pengawas dalam penghimpunan dana kas masjid. Pelaporan tidak langsung dilakukan 1 bulan sekali. Hal ini dirasa efektif karena tugasnya pengawas adalah mengawasi dan memastikan apakah dalam penghimpunan dana kas masjid berjalan sesuai rencana atau tidak. Pengawas harus bisa memastikan bahwa semua kegiatan dapat berjalan dengan lancar dan mengetahui kendala yang terjadi di lapangan.

\section{Simpulan}

Berdasarkan hasil pembahasan pengukuran kinerja keuangan wakaf dan manajemen wakaf masjid dapat disimpulkan bahwa:

1. Kinerja keuangan wakaf di masjid Sabilillah Malang dikatakan baik. Penelitian ini mengadopsi dari penelitian Ritchei dan Kolodinsky (2003) dan Shafii et al (2012) menggunakan rasio total pendapatan, pendapatan operasional, pertumbuhan pendapatan, kontribusi program, biaya penghimpunan dana, efisiensi administrasi, efisiensoi program, dan ketersediaan uang tunai. Dari kedelapan rasio tersebut dapat disimpulkan bahwa kinerja keuangan di masjid Sabilillah dibilang cukup baik karena memenuhi kriteria dari penelitian sebelumnya. Manajemen wakaf di Sabilillah juga terorganisir dengan baik sesuai dengan jobdisk masingmasing.

2. Dalam pengelolaan harta wakaf mengalami kendala seperti nadzir yang masih pasif dalam mengawasi pengelolaan wakaf, namun segala sesuatu dilaksanakan dengan semaksimal mungkin dan direncanakan dengan maksimal untuk memberikan pemahaman yang sama pada pengelola wakaf di masjid Sabilillah.

\section{Saran}

Berdasarkan hasil penelitian, pengelolaan wakaf di masjid Sabilillah Malang secara umum baik, namun lebih baik jika sistem pelaporan keuangannya dipublikasikan secara umum sehingga memudahkan masyarakat untuk mengakses. Hal ini dikarenakan masjid Sabilillah menjadi masjid percontohan wakaf produktif bagi masjid-masjid lainnya. Dalam manajemen wakaf diharapkan nadzir lebih optimal dalam mengambangkan wakaf dengan baik sehingga dapat dijadikan contoh bagi masjid-masjid lainnya dalam hal pengelolaan dan manajemen wakaf.

\section{Referensi}

Abas, F. N., \& Raji, F. (2018). Factors Contributing to Inefficient Management and Maintenance of Waqf Properties: A Literature Review. UMRAN - International Journal of Islamic and Civilizational Studies, 5(3), 53-67. https://doi.org/10.11113/umran2018.5n3.233 
Arshad, R., \& Mohd Zain, N. (2017). Performance Measurement and Accountability of WAQF Institutions in Malaysia . SHS Web of Conferences, 36, 00005. https://doi.org/10.1051/shsconf/20173600005

Arshad, R., Zain, N. M., Urus, S. T., \& Chakir, A. (2018). Modelling Maqasid Waqf performance measures in Waqf institutions. Global Journal Al-Thaqafah, 2018(January), 157-170. https://doi.org/10.7187/gjatsi2018-11

Epstein, M. J Buhovac, AR (2009) .Performance Pengukuran Tidak-Bisnis Organizations.Retrieved dari http://www.ef.unilj.si/docs/osebnestrani/Not-forProfit.pdf

Karens, Sanders M. (2008). An Analysis of Florida Public Community Collage Foundations Performance Measures From 2002-2004. Dissertation. University of Central Florida Orlando, Florida.

Kementrian Agama Republik Indonesia, Direktorat Jenderal Bimbingan Masyarakat Islam, D. P. W. (2006). Fiqih Wakaf. 1-126.

Laldin, M. A., \& Furqani, H. (2013). Developing Islamic finance in the framework of maqasid al-Shari ' ah. https://doi.org/10.1108/IMEFM05-2013-0057

Mangkunegara, Anwar Prabu. (2001). Manajemen Sumber Daya Manusia Perusahaan. Bandung: Remaja Rosdakarya.
Noordin, N. H., Haron, S. N., \& Kassim, S. (2017). Developing a comprehensive performance measurement system for waqf institutions. 44(7), 921-936. https://doi.org/10.1108/IJSE-09-20150257

Ritchei, William J and Kolodinsky, Robert. W. (2003) Nonprofit Organization Financial Performance Measure: An Evaluation of New and Existing Financial. Nonprofit Management \& Leadership, vol. 13, no. 4, Summer 2003

Rozalinda. (2015). Manajemen Wakaf Produktif. Jakarta: Raja Grafindo Persada

Rusdan, R. (2016). Urgensi Manajemen Pengawasan Risiko Bank Syariah. Palapa, 4(2), 85-103.

Shafii, Z., Yunanda, R. A., \& Rahman, F. K. (2012). Financial and Operational Measures of Waqf Performance: the Case of State Islamic Religion. 345-359. https://doi.org/10.1254/jjp.19.148

Siwak Kemenag diakses pada tanggal 16 Desember 2019.

Sutopo, Ariento Hadi dan Adrianus Arief. (2010). Terampil Mengolah Data Kualitatif. Jakarta: Penerbit Prenada Media Group.

Wirawan. (2009). Evaluasi Kinerja Sumber Daya Manusia. Jakarta: Penerbit Salemba Empat. 